\title{
High-speed rail impact on urban economic growth -Based on grey prediction model
}

\author{
Yiping Wei $i^{1, a}$ \\ ${ }^{1}$ Beijing Jiaotong University, China \\ a17120536@bjtu.edu.cn
}

Keywords: High-speed railway, Urban economic growth, $\mathrm{GM}(1,1)$ model, Contribution rate.

\begin{abstract}
With the rapid development of high-speed railways, China has entered the era of highspeed rail. High-speed railways inject new impetus into the economic development of the city and enable the economy to achieve a new leap-forward development. This article takes Changsha City as an example to evaluate high-speed railways using comparative evaluation methods. It is assumed that under the conditions of "having high-speed rail" and "without high-speed rail" the impact of highspeed railway on regional economic development will be discussed by the regression model and gray predict the GM(1,1) model. The results show that the opening of high-speed rail has a pulling effect on urban economic growth and the contribution rate to economic growth shows a tendency of increasing first and then decreasing. Particularly, the contribution of high-speed rail to the economic growth in the first few years is swift and violent, with significant impact, then slows down.
\end{abstract}

\section{Introduction}

With the development of high-speed railways, the impact of high-speed rail on urban economic development is also gradually strengthened. High-speed rail has a great influence on all aspects of urban economic development. Because of the high-speed rail's own effects and characteristics, it has a strong mobility for the mobilization of funds, technology, and manpower. Therefore, it will certainly create undeniable influence in the process of economic development.

\section{Literature review}

Yechun $\mathrm{Wu}$ (2009) analyzes the impact of the Wuhan-Guangzhou high-speed railway construction on the development of the urban system along the route from three aspects of the hierarchical structure, spatial structure, and functional structure of the urban system. There is no deeper study of the urban economic realm [1]. Wei Zhang (2010) analyzed the technical and economic advantages of highspeed railways and explained that the impact of high-speed railways on the economic development along the region is extremely important for regional development [2]. Weifeng Yang (2010) The Beijing-Shanghai high-speed railway speeds up the circulation of spatial elements of modern service industry, expands the spatial differentiation of the distribution of production factors, and forms different forms of spatial organization [3]. Mingming Hou (2010) proposed that there are catalysis and catalysis between the construction of integrated transportation hubs and regional development, and they are not driven and driven [4]. $\mathrm{Lu} \mathrm{Xu}$ and $\mathrm{Xu}$ Hao pointed out that the high-speed rail economy refers broadly to relying on the comprehensive advantages of high-speed railways to promote capital, technology, manpower and other production factors [5].

\section{Evaluating the impact of high-speed railway on economic growth (Changsha's high-speed railway as an example)}

This paper first establishes a regression analysis model, which is obtained from 2001-2009 data fitting. The regression equation of railway passenger volume and economic growth without high-speed rail is forecasted by the grey forecasting method $\operatorname{GM}(1,1)$ when there is no high-speed railway in 20102015 Railway passenger traffic. By comparing the economic growth indicators without high-speed 
rail with the actual economic growth indicators after the opening of the high-speed rail, the quantitative analysis and research on the contribution of high-speed rail to Changsha's economic growth will be conducted.

\subsection{Selection of indicators}

Relevant indicators of economic growth: From the perspective of total economic growth and structural growth, select Changsha City's gross domestic product (GDP), total domestic tourism revenue, real estate development investment, and the added value of the first, second, and third industries.

Table 1. Various economic indicators for high-speed rail in 2001-2015.

\begin{tabular}{cccccccc}
\hline Year & $\begin{array}{c}\text { Railway } \\
\text { passenger } \\
\text { traffic } \\
(10,000 \\
\text { people })\end{array}$ & $\begin{array}{c}\text { GDP } \\
\text { (billion } \\
\text { yuan) }\end{array}$ & $\begin{array}{c}\text { Total domestic } \\
\text { tourism } \\
\text { revenue }(100 \\
\text { million yuan })\end{array}$ & $\begin{array}{c}\text { Real estate } \\
\text { development } \\
\text { investment } \\
(100 \text { million } \\
\text { yuan })\end{array}$ & $\begin{array}{c}\text { Value added } \\
\text { in primary } \\
\text { industry } \\
(100 \text { million } \\
\text { yuan })\end{array}$ & $\begin{array}{c}\text { Value added } \\
\text { by the second } \\
\text { industry (100 } \\
\text { million yuan) }\end{array}$ & $\begin{array}{c}\text { Value added } \\
\text { by the third } \\
\text { industry (100 } \\
\text { million yuan) }\end{array}$ \\
\hline 2001 & 1070 & 728.08 & 79.79 & 63.19 & 78.37 & 297.09 & 352.62 \\
\hline 2002 & 984 & 812.85 & 90.28 & 81.56 & 80.7 & 337.3 & 394.9 \\
\hline 2003 & 942 & 929.49 & 115.4 & 110.83 & 83 & 393.92 & 451.3 \\
\hline 2004 & 1187 & 1133.9 & 126.3 & 175.5 & 103.33 & 492.57 & 512.95 \\
\hline 2005 & 1218 & 1519.9 & 132.17 & 255.61 & 112.59 & 665.27 & 752.04 \\
\hline 2006 & 1243 & 1799 & 151.95 & 303.86 & 123.25 & 774.66 & 892.75 \\
\hline 2007 & 1305 & 2190.3 & 204.6 & 407.05 & 138.8 & 984.83 & 1066.63 \\
\hline 2008 & 1442 & 3001 & 271.2 & 493.27 & 172.38 & 1567.41 & 1261.19 \\
\hline 2009 & 1479 & 3745 & 324.8 & 497.35 & 179.4 & 1893.59 & 1671.78 \\
\hline 2010 & 1642 & 4547.1 & 422.3 & 684.1 & 202 & 2437 & 1908 \\
\hline 2011 & 1816 & 5619.3 & 543.5 & 926.01 & 243.38 & 3151.68 & 2224.26 \\
\hline 2012 & 1954 & 6399.9 & 741.1 & 1034.35 & 272.3 & 3592.5 & 2535.1 \\
\hline 2013 & 2088 & 7153.1 & 958 & 1157.63 & 294.55 & 3946.97 & 2911.61 \\
\hline 2014 & 2188 & 7824.8 & 1143.6 & 1313.62 & 311.9 & 4241.25 & 3271.66 \\
\hline 2015 & 2394 & 8510.1 & 1302.6 & 1006.84 & 341.78 & 4333.58 & 3834.77 \\
\hline
\end{tabular}

\subsection{Regression model establishment}

Changsha opened a high-speed railway and used data from 2001 to 2009 to establish a regression equation for the relationship between passenger volume and GDP $\left(\mathrm{y}_{1}\right)$, domestic tourism revenue $\left(\mathrm{y}_{2}\right)$, real estate development investment $\left(\mathrm{y}_{3}\right)$, the value added of primary $\left(\mathrm{y}_{4}\right)$, secondary $\left(\mathrm{y}_{5}\right)$, and tertiary $\left(\mathrm{y}_{6}\right)$ industries without high-speed rails [6]. Linear regression model equation:

$$
\mathrm{y}_{n t}=\mathrm{a}+\mathrm{bx}_{t}
$$

Among them, $n=1,2,3,4,5,6 ; \mathrm{t}=2001,2002,2003,2004,2005,2006,2007,2008,2009$. a, $\mathrm{b}$ are the parameters to be estimated, $\mathrm{x}_{t}$ is the passenger traffic in the $\mathrm{t}$-th year (million people), and $\mathrm{y}_{n t}$ is the value of the nth economic indicator in the $t$-th year.

Table 2. Regression equations of railway passenger traffic and various economic indicators without high-speed rail.

\begin{tabular}{cccc}
\hline & Quasilinear equation & $\mathrm{R}^{2}$ & $\mathrm{P}$ \\
\hline Equation (1) Changsha's GDP & $\mathrm{y}_{1 t}=5.9 \mathrm{x}_{t}-5345.57$ & 0.8675 & 0.0000 \\
\hline $\begin{array}{c}\text { Equation (2) Total domestic tourism } \\
\text { revenue }\end{array}$ & $\mathrm{y}_{2 t}=0.8594 \mathrm{x}_{t}-874.58$ & 0.8205 & 0.0000 \\
\hline $\begin{array}{c}\text { Equation (3) Real estate development } \\
\text { investment }\end{array}$ & $\mathrm{y}_{3 t}=0.8839 \mathrm{x}_{t}-785.07$ & 0.9052 & 0.0000 \\
\hline $\begin{array}{c}\text { Equation (4) Value added in primary } \\
\text { industry }\end{array}$ & $\mathrm{y}_{4 t}=0.1953 \mathrm{x}_{t}-116.34$ & 0.9314 & 0.0000 \\
\hline $\begin{array}{c}\text { Equation (5) Value added by the second } \\
\text { industry }\end{array}$ & $\mathrm{y}_{5 t}=3.2979 \mathrm{x}_{t}-3105.62$ & 0.8492 & 0.0000 \\
\hline $\begin{array}{c}\text { Equation (6) Value added by the third } \\
\text { industry }\end{array}$ & $\mathrm{y}_{6 t}=2.4392 \mathrm{x}_{t}-2129.65$ & 0.8606 & 0.0000 \\
\hline \begin{tabular}{c} 
El \\
\hline
\end{tabular} & & &
\end{tabular}


Among the above six regression equations, the $\mathrm{R}^{2}$ value is higher than 0.80 and the regression equation has a good fitting effect. At the same time, the coefficient test $\mathrm{P}$ of these six fitting equations is $0.000<0.05$. Thus, empirical analysis of regression analysis shows that the amount of railway passenger transport has a significant impact on GDP, domestic tourism revenue, real estate development investment, and the value added of the first, second, and third major industries [6].

\subsection{Gray prediction model establishment}

Establish a grey prediction GM $(1,1)$ model to predict the railway passenger traffic in the absence of high-speed rail in Changsha City during 2010-2015.

Table 3. Railway passenger transport volume 2001-2009 .

Unit: 10,000

\begin{tabular}{cccccccccc}
\hline year & 2001 & 2002 & 2003 & 2004 & 2005 & 2006 & 2007 & 2008 & 2009 \\
\hline $\mathrm{X}(0)$ & 1070 & 984 & 942 & 1187 & 1218 & 1243 & 1305 & 1442 & 1479 \\
\hline
\end{tabular}

Then, establish a first order linear differential equation for $\mathrm{x}(1)(\mathrm{k})$ :

$$
\frac{d x^{(1)}}{d t}+a x^{(1)}(t)=u \text {. }
$$

Accumulate to form a sequence of new data: $x^{(1)}$. Where $a$ and $b$ are the coefficients to be estimated. In the MATLAB 20 software programming calculation, draws the underestimation parameter a=$0.0612, b=883.7166$, then the time response function of the railway passenger GM $(1,1)$ model is: $\mathrm{x}(1)(\mathrm{k})=15501.97 * \exp (0.0612 \mathrm{k})-14431.97$,Substituting this equation to calculate the predicted value of railway passenger traffic without high-speed rail during 2010-2015 is: $\mathrm{x}=[1596.363,1698.539,1805.796,1919.825,2041.056,2169.942]$. After the model test, the post-test variance ratio $\mathrm{C}=18.2727 \%<0.35$, small error $\mathrm{P}=1$, so the model fitting effect is good, and the predicted no-high-speed railway passenger traffic data is available [7].

\subsection{Empirical results and analysis}

By substituting the prediction of the passenger traffic of high-speed trains during 2010-2015 into the regression equation of Table 1, six economic indicators without high-speed rails can be calculated. Then compare and analyze the economic indicators of the high-speed rails actually opened during 2010-2015 and calculate the contribution rate of the high-speed rail to the economic growth index $(\%)=($ high-speed rail-without high-speed rail)/(without high-speed rail)*100\% [6].

Table 4. Comparing the economic indicators of high-speed railway with and without high speed rail in 2010-2015

\begin{tabular}{|c|c|c|c|c|c|c|c|}
\hline & & 2010 & 2011 & 2012 & 2013 & 2014 & 2015 \\
\hline \multirow{3}{*}{ GDP } & high-speed rail & 4547.1 & 5619.33 & 6399.9 & 7153.1 & 7824.81 & 8510.13 \\
\hline & without high-speed rail & 3760.97 & 4292.3 & 4850 & 5443 & 6073.3908 & 6743.6 \\
\hline & contribution rate & $20.90 \%$ & $30.92 \%$ & $31.96 \%$ & $31.42 \%$ & $28.84 \%$ & $26.20 \%$ \\
\hline \multirow{3}{*}{$\begin{array}{c}\text { Total } \\
\text { domestic } \\
\text { tourism } \\
\text { revenue }\end{array}$} & high-speed rail & 422.3 & 543.5 & 741.1 & 958 & 1143.6 & 1302.6 \\
\hline & without high-speed rail & 324.484 & 366.085 & 409.75 & 456.2 & 505.523 & 557.993 \\
\hline & contribution rate & $30.14 \%$ & $48.46 \%$ & $80.87 \%$ & $110.0 \%$ & $126.22 \%$ & $133.44 \%$ \\
\hline \multirow{3}{*}{$\begin{array}{l}\text { Real estate } \\
\text { development } \\
\text { investment }\end{array}$} & high-speed rail & 684.1 & 926.01 & 1034.5 & 1157.6 & 1313.62 & 1006.84 \\
\hline & without high-speed rail & 603.738 & 692.707 & 786.11 & 885.4 & 990.971 & 1103.21 \\
\hline & contribution rate & $13.31 \%$ & $33.68 \%$ & $31.58 \%$ & $30.75 \%$ & $32.56 \%$ & $-8.74 \%$ \\
\hline \multirow{3}{*}{$\begin{array}{l}\text { Value added } \\
\text { in primary } \\
\text { industry }\end{array}$} & high-speed rail & 202 & 243.38 & 272.3 & 294.55 & 311.9 & 341.78 \\
\hline & without high-speed rail & 195.49 & 215.59 & 236.69 & 259.12 & 282.965 & 308.317 \\
\hline & contribution rate & $3.33 \%$ & $12.89 \%$ & $15.04 \%$ & $13.67 \%$ & $10.23 \%$ & $10.85 \%$ \\
\hline \multirow{3}{*}{$\begin{array}{c}\text { Value added } \\
\text { by the } \\
\text { second } \\
\text { industry }\end{array}$} & high-speed rail & 2437 & 3151.68 & 3592.5 & 3947 & 4241.25 & 4333.58 \\
\hline & without high-speed rail & 1906.83 & 2191.83 & 2491.0 & 2809.1 & 3147.2173 & 3506.71 \\
\hline & contribution rate & $27.80 \%$ & $43.79 \%$ & $44.22 \%$ & $40.51 \%$ & $34.76 \%$ & $23.58 \%$ \\
\hline \multirow{3}{*}{$\begin{array}{l}\text { Value added } \\
\text { by the third } \\
\text { industry }\end{array}$} & high-speed rail & 1908 & 2224.26 & 2535.1 & 2911.6 & 3271.66 & 3834.77 \\
\hline & without high-speed rail & 1685.43 & 1913.70 & 2153.3 & 2408.1 & 2678.92 & 2966.87 \\
\hline & contribution rate & $13.21 \%$ & $16.23 \%$ & $17.73 \%$ & $20.91 \%$ & $22.13 \%$ & $29.25 \%$ \\
\hline
\end{tabular}




\section{Summary}

\subsection{Economic growth analysis}

From 2010 to 2015, GDP of high-speed railways in Changsha is much higher than that without highspeed rails, which indicates that the opening of high-speed railways has a significant role in promoting economic growth. The contribution rate to GDP is increased first and then decreased, indicating that the impact of high-speed rail on economic growth is fluctuation. The contribution rate during the four years from 2010 to 2013 has gradually increased and reached a peak in 2013 and then declined in the following two years. This shows that the impact of high-speed rail on economic growth has been rapid in the just-opened year, with significant efficiency gains. Particularly, the high-speed rail is driving the growth of urban tourism economy significantly, which is significantly higher than the contribution rate of other economic indicators. The contribution of high-speed railways to the growth of real estate development investment will increase first and then decrease. The high-speed rail is the artery of urban development and it gives new energy to the development of the urban economy.

\subsection{Analysis of economic structure growth}

The contribution rate of high-speed trains to the three major industries also increases first and then decreases. This has a significant impact in the first few years of the high-speed rail operation, which is consistent with the impact on GDP growth. The opening of high-speed rail has a positive effect on the growth of the primary, secondary and tertiary industries, and the secondary industry contributes more than the tertiary industry. As can be seen from the primary industry indicators in Table 3, during the first year of the high-speed rail opening in 2010, the contribution rate of high-speed rail development to the primary industry was not very large, and the contribution rate of the high-speed rail economy began to increase sharply in 2011. It is reflected in the primary industry. The development and improvement of the urban transport system has provided convenient conditions, thus promoting the sustainable development of the agricultural economy.

\section{Acknowledgement}

I want to deeply thank my mentor, Xuemei Li. Miss Li is modest and approachable. She has devoted great care and encouragement to the topic selection, data collection and writing of the thesis.

\section{References}

[1] Yechun Wu. Research on the Influence of Wuhan-Guangzhou High-Speed Railway on the Development of Urban System along the Line[D]. Southwest Jiaotong University, 2009.

[2] Wei Zhang. Thoughts on the Impact of High-speed Railway on Regional Economic Impact[J]. Shanghai Railway Science and Technology,2010(02):12-13.

[3] Weifeng Yang. Analysis of the Impact of Beijing-Shanghai High-speed Railway on Regional Spatial Structure in China[J]. Beijing Social Sciences,2010(06):38-43.

[4] Mingming Hou. Research on the construction of integrated transportation hub and regional development under the influence of high-speed rail[D]. Tongji University, 2008.

[5] $\mathrm{Xu} \mathrm{Lu}, \mathrm{Hao} \mathrm{Xu}$. Thinking about the development of small and medium-sized cities along the high-speed rail economy[J]. Oriental Corporate Culture,2011(10):120.

[6] Li Zhang, Xiaotao Wu. An Empirical Analysis of the Effect of High Speed Rail on Urban Economic Growth[J]. Statistics \& Decision,2017(17):152-154.

[7] Li Zhang, Xiaotao Wu. An Empirical Analysis of the Effect of High Speed Rail on Urban Economic Growth[J]. Statistics \& Decision,2017(17):152-154. 